\title{
20/21: WHAT HAVE WE LEARNED?
}

\section{Keywords}

20/21

Pandemic

Coexistence

Critique

Debate
The pandemic made us change our ways of life, both domestically and publicly. With no certainty about the future and no confidence in the past, we move into a weird present in which our expectations are on hold, but our senses are more active than ever. Meanwhile, the question about the city's future after the pandemic (and therefore, of architecture) has taken a space previously occupied by business leadership or financial analysis seminars. We are living at a turning point, without much idea of where our destiny will turn. The temporal and spatial arc between 2019 in the streets to 2020 in confinement led us to wonder whether something will remain the same. We have seen how the solidity of the

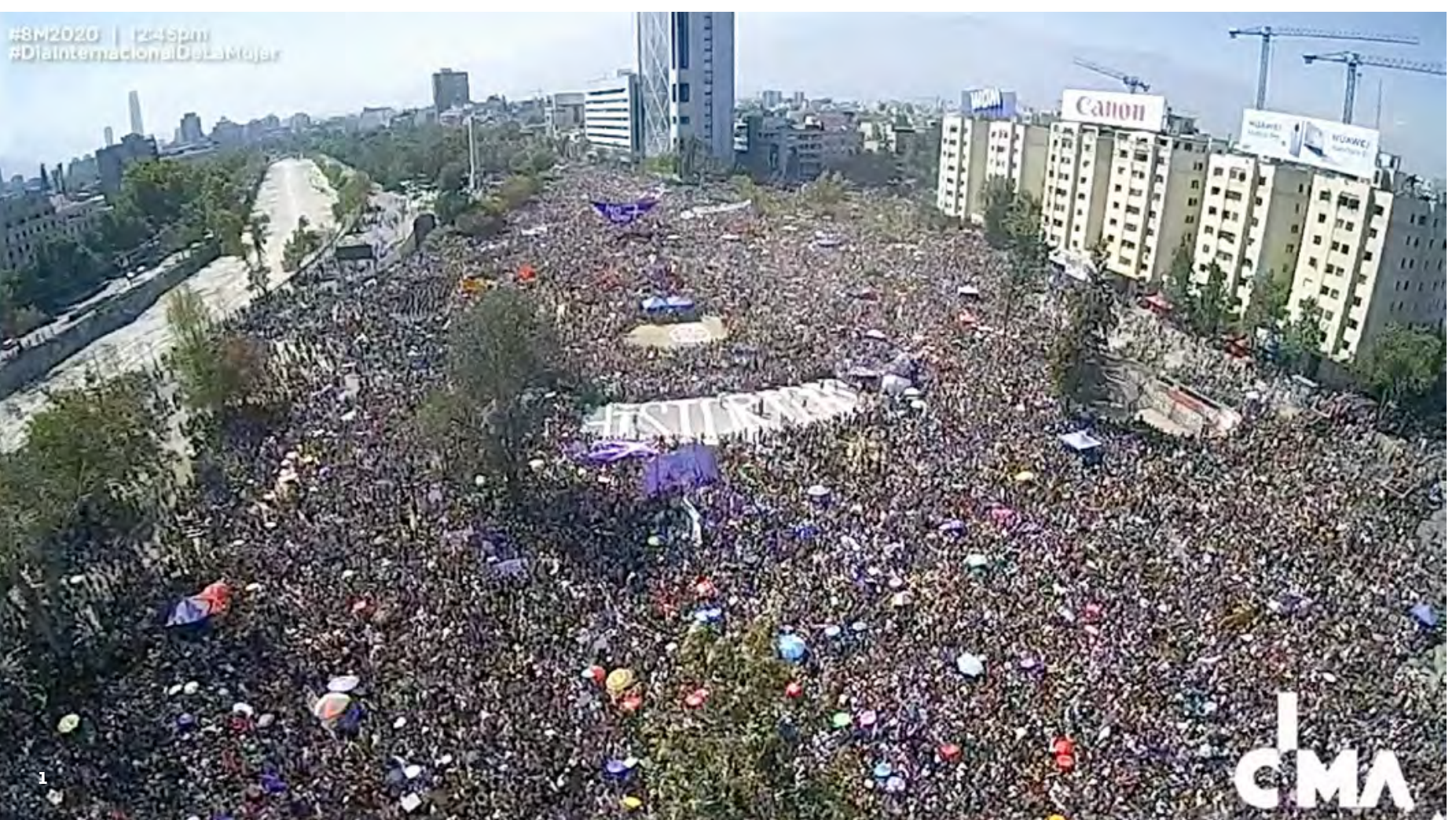


grounds on which we are accustomed to living was diluted. That which the real threat of global warming did not accomplish, the spread of a virus forced us to accept. Our hopes - those that remain - are pinned on this new year. Hence, between 2020 and 2021 there is a break, a cut. The 'slash' separating the 20 and the 21 in this issue's title marks that disruption, that change. Have we learned anything from all this? Does what we have recently experienced change our point of view? Or will we pretend nothing happened and continue as we have been until now?
1 Marcha Día Internacional de la Mujer. Plaza Dignidad, Santiago, 8 de marzo de 2020 / International Women's Day March

Plaza Dignidad, Santiago, March 8, 2020. (C) Galeria ci Ma | www.galeriacima.cl

2 Plaza Dignidad durante cuarentena. Santiago, 28 de marzo de 2021 / Plaza Dignidad during quarantine. Santiago, March 28, 2021.

(C) Galeria ci Ma

www.galeriacima.cl

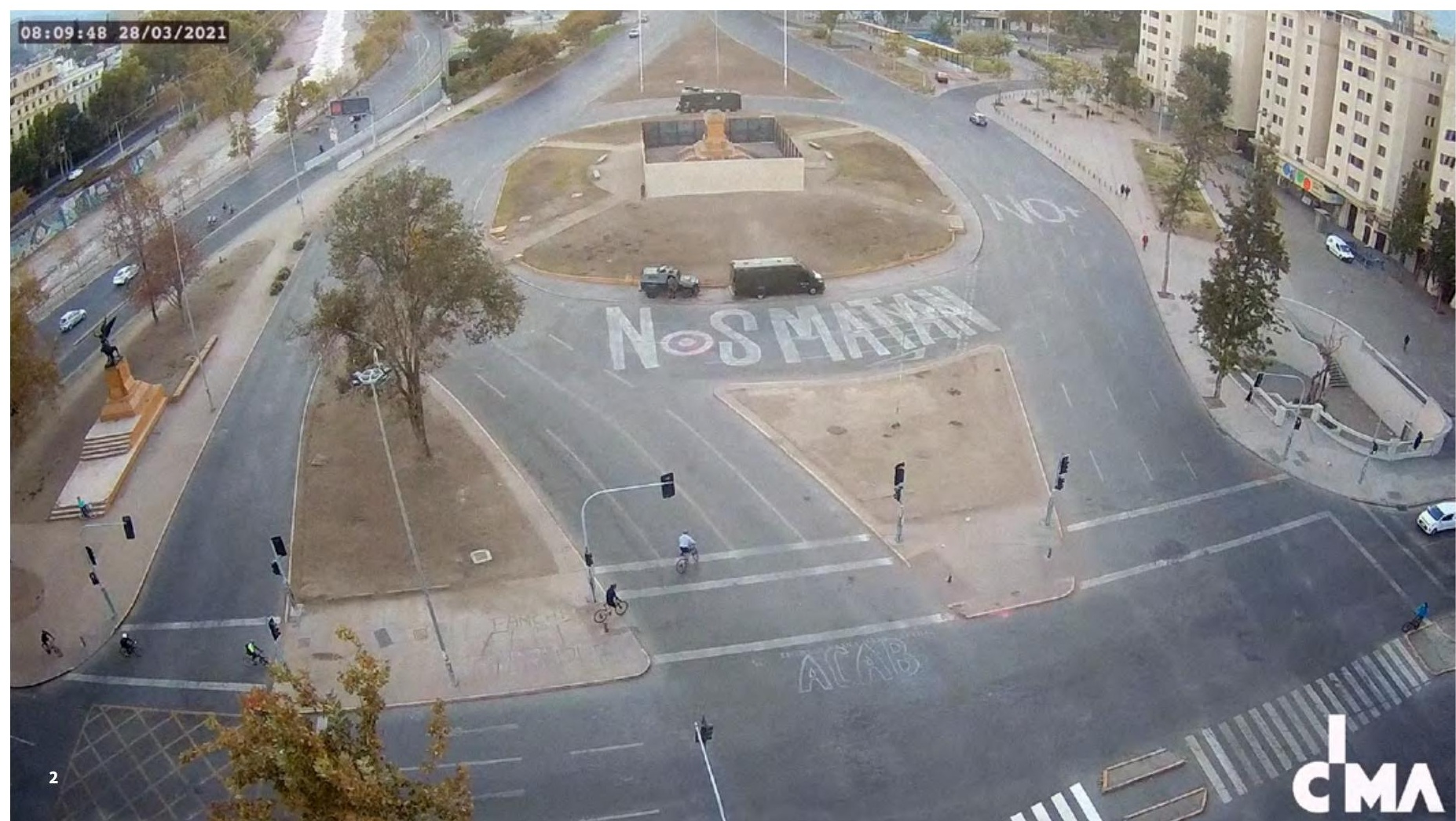




\section{Twilight Architecture.}

Some notes on gray areas

n 2006, with the students' demonstrations - the

Penguin Revolution - as a backdrop, the Japanese magazine $A+U$ dedicated its 43othissue to Chilean architecture. The publication accounted for a sober and insular character, highlighted by the cover photograph, where a copper house stands out in a misty atmosphere. Under the title, "Chile - Deep South", the issue celebrated remarkable projects, their 'dialogue' with nature, the emergence of new practices, a measured repertoire in the use of materials, and, at the same time, a political and economic stability that served as a support for all of the above. Optimism was declared over fifteen years after the return of democracy, where the route or ways of operating were drawn without much critical correction, both for offices and schools of architecture.

In March 2020, fourteen years later, preceding the first quarantines and in a context of protests and social demands, $A+U$ published a new monographic issue. The cover of "Architecture in Chile. In Search of a New Identity," showed a semi-buried building among industrial masonry ruins, with a city of housing towers and informal expansions reaching into the desert. The mist dissipates and what appears is a context much more complex and difficult to ignore.

What at first glance can be read as another triumph in the local obsession of standing out globally, rather accounts for the latter stages of a cycle. As in the twilight western of the sixties, the exhaustion of what seemed like a virtuous moment becomes evident, an exhaustion in which previously celebrated objectives brought their own decay. This does not imply the disappearance of a way of working but instead promotes dealing with increasingly obvious gray areas in a world of changing values. Here comes the disbelief, the nostalgia, or the pessimism. A mood that is closer to The Wild Bunch, the 1969 film and emblem of the twilight western, than to a 'golden generation,' a title that could perfectly fit a classic western.

The architecture developed in recent decades in the vastness of the landscape, on the white mountain, has gone hand in hand with the unbridled privatization of the same territories that these buildings sought to highlight. 
(or third) homes with a strong interdependence of other populated centers, which, in many cases, have little urban planning to receive this number of visitors.

At the same time, the celebrated sobriety and economics of material resources reflected in reinforced concrete works entail a type of seismic-resistant construction, but also a highly polluting one. Safety, aesthetic fascination, and energy efficiency come into tension. The condition of ruin in these one-piece buildings became more evident during the pandemic, where many of them entered a forced abandonment.

From the above, the challenge arises two possible responses: continuing to build as in recent decades or to intervene on what already exists. Projects of various scales, public and private, collect fragments of a city that preserves and destroys at different rhythms. By flirting with gentrification, some of these works are the very cause of the transformation of the environment and its social fabric.

And perhaps here appears an unfinished problem for this twilight moment: how to live together? Of the thirty-one projects published in the two Japanese magazines dedicated to Chile, we can only find one high-rise building of collective housing. A thick work, raw in its details, of low density, and very suggestive in its circulations and common space. A void to be filled when everything seems like a desert anchored in the Twentieth-century. ARQ 